\title{
Type of Event
}

National Cancer Institute

\section{Source}

National Cancer Institute. Type of Event. NCI Thesaurus. Code C53053.

A particular categ ory of events regarded as having particular characteristics, qualities, and/or defined similarities. 